of the Pliocene. Following is a description of the fossils:

Here follow twenty-two pages, pages from 205 to 226 , describing the fossils of the Quillayute formation. I will add that I described no fossils whatever from the glacial deposits, or Quaternary deposits of the Olympic Peninsula. Furthermore in describing each fossil I gave a notation after it telling where it had been found; for example, take Yoldia cooperi, fossil number 34, described on page 206 of the article. The notation following the description is as follows:

Living: Half Moon Bay, California (Arnold); San Diego to Santa Cruz (Cooper).

Pleistocene: Ventura, San Diego, Cal. (Arnold); San Pedro (Arnold; Cooper).

Pliocene: San Fernando (Cooper); Portata Valley, California (Arnold).

?Pliocene: Mouth of Quinaielt River, Granville, Wash. (Arnold), Quillaỹute, Wash. (Reagan).

Again take number 35, Cardium meekianum Gabb, on the same page. The notation is:

This is quite a numerous species of the Pliocene at Quillayute, Wash.

Pliocene: Humboldt county, California (Gabb); Quillayute, Wash. (Reagan).

In correlation, the sandstone and bluish shale of the Quillayute formation, which I definitely described in my article as composing the formation, is typical Empire sandstone and shale.

Principal, U. S. Indian School, IGNacto, Colorado

\section{NOMENCLATORIAL FACTS}

Two cases have been recently cited in the present journal by Mr. A. N. Caudell as showing nomenclatorial inconsistency in the attitude of the present writer. That this is true, or that, as Mr. Caudell infers, unanimity among systematists is hopeless, we are entirely unprepared to admit.

In the first case we have claimed that Pedeticum of McNeill is preoccupied by Pedeticus of Laporte. ${ }^{1}$ As the International Code has as yet not acted on this matter, we are led to this decision by Canon 20, page lviii, 1898, of the

1 Ent. News, XXVII., p. 17 (1916).
A. O. U. Code. Mr. Caudell refers to Article 36 of the International Code, but indirectly quotes only a recommendation there found. Such recommendations have been admitted, by the secretary of the International Commission, to have no force of law. Furthermore, Opinion 25 of the International Commission, also cited by Mr. Caudell, does not bear on the subject, as in the present case the matter involved is simply a case of different gender termination, while in the case of Damesella and Damesiella the Commission, in Opinion 25, is obliged to fall back on Section $K$ of Recommendation of Article 8, "a name composed of arbitrary combinations of letters." The results obtained were the International Code to disagree with the A. O. U. Code would create such difficulties that we feel confident that the International Code will be found to agree with that of the A. O. U., when this matter is finally acted upon. As an instance, in the case of Aplodontia, twenty-four emendations have already been found and cited by Palmer, ${ }^{2}$ the confusion possible, were each of these eligible for distinct generic rank, is evident.

In regard to Libell[ula] americanus, Drury nowhere in his work suggests a different generic position for this name. The use of Libellula may constitute a lapsus calami, but it would seem an assumption that Gryllus is the intended genus, where Locusta or Acrydium might have been intended. We regret that we feel obliged to criticize the quoted opinion of Dr. Stiles and concurrence in the same of Dr. Stejneger. Drury's index, in which Libell[ula] americanus is found is not known to be of a later date than his first volume; it is Westwood, in his edition of Drury, who first suggests Gryllus to replace Libellula for this species, and the "obvious" lapsus calami is not as obvious or as easily disposed of when the original edition of Drury is considered. It appears probable that Dr. Stiles's unofficial opinion is based rather upon secondhand information than upon examination of the original edition of Drury.

We are strongly in favor of both of these cases being brought before the Commission 2 “'N. A. Fauna,", XXIII., p. 25 (1904). 
for a final decision; the former for a muchneeded rule as to whether or not "a generic name is to be considered identical whether the ending is masculine, feminine or neuter" if from the same root; the latter for an official opinion as to whether a lapsus calami does or does not exist in the case of Libell[ula] americanus Drury.

In the meantime we feel that our action is as clear and consistent as is possible, our aim being to follow the official decisions of the International Code, and, in cases where action has not as yet been taken, to follow that course which, after careful consideration, we believe most likely to coincide with the later rulings of that body.

We naturally do not relish our work being used as a striking illustration of the hopelessness of unanimity among systematists on nomenclatorial matters, but we could hardly hope for a less gloomy viewpoint from one of the authors of "The Entomological Code" the first rule of which recommends in the vernacular " everybody for himself."

Chestinut Hill, Pa.

\section{Morgan Hebard}

\section{SYLVESTER AND CAYLEY}

ON page 781 of the last volume of ScIENCE there appeared a criticism relating to a statement in my recent book entitled "Historical Introduction to Mathematical Literature." The statement in question seems to be the following: "Cayley and Sylvester were students at Cambridge at the same time and formed then a lifelong friendship," which appears on page 259. In view of the fact that a "colossal error" is said to have been committed it may be of interest to compare the given sentence with the following quotation from the third edition, page 484, of "A Short Account of the History of Mathematics," by W. W. R. Ball:

$\mathrm{He}$ (Sylvester) too was educated at Cambridge, and while there formed a life-long friendship with Cayley.

The same statement appears in the fifth edition (1912) of Ball's "History" and an equivalent form of it is found in the reviewed and augmented French translation of the third edition.

The fact that Ball has been connected with Trinity College, Cambridge, for a long time and that he was Fellow of this college during many years while Cayley was professor in the University of Cambridge led me to place more confidence in the given statement as a reliable historical fact than I should otherwise have done. While I do not now recall all the evidence at hand when writing the sentence which has been the subject of said criticism, it appears to me that the given evidence is sufficient to warrant this sentence until it can be proved that this evidence is unreliable.

G. A. Miller

UNIVERSITY OF ILLINOIS

\section{SCIENTIFIC BOOKS}

Fundamental Conceptions of Modern Mathematics, Variables and Quantities, with a Discussion of the General Conception of Functional Relation. By RoBerT P. RICHaRdson and Edward H. Landis. Chicago and London, The Open Court Publishing Company, 1916. Pp. xxi +216 .

According to the announcement near the end of the present volume "that portion of 'Fundamental Conceptions of Modern Mathematics' dealing with algebraic mathematics will consist of thirteen parts." The volume under review is Part I. and has as subtitle "Variables and Quantities with a Discussion of the General Conception of Functional Relation." The magnitude of this undertaking and the fundamental character of the questions considered combine to direct unusual attention to the project, and hence the present volume is of interest not only on its own account, but also on account of the hopes or fears it may inspire as regards the remaining volumes of the projected series.

A striking feature of this volume, which will doubtless create at the start an unfavorable impression on many mathematical readers, is the somewhat harsh criticism of some of the work of many eminent mathematicians, including Baire, Bauer, Pringsheim, Riemann, Russell, Weber, and many others. For in- 